\title{
Micromonospora humi sp. nov., isolated from peat swamp forest soil
}

\author{
Apakorn Songsumanus, ${ }^{1}$ Somboon Tanasupawat, ${ }^{1}$ Chitti Thawai, ${ }^{2}$ \\ Khanit Suwanborirux ${ }^{3}$ and Takuji Kudo ${ }^{4}$
}

Correspondence
Somboon Tanasupawat
Somboon.T@chula.ac.th

\author{
${ }^{1}$ Department of Biochemistry and Microbiology, Faculty of Pharmaceutical Sciences, Chulalongkorn \\ University, Bangkok 10330, Thailand \\ ${ }^{2}$ Department of Biology and Microbiol Resource Management Unit, Scientific Instrument Center, \\ Faculty of Science, King Mongkut's Institute of Technology, Ladkrabang, Bangkok 10520, \\ Thailand \\ ${ }^{3}$ Department of Pharmacognosy and Pharmaceutical Botany, Faculty of Pharmaceutical Sciences, \\ Chulalongkorn University, Bangkok 10330, Thailand \\ ${ }^{4}$ Japan Collection of Microorganisms, RIKEN BioResource Center, Wako, Saitama 351-0198, \\ Japan
}

\begin{abstract}
A novel actinomycete, strain $\mathrm{P} 0402^{\top}$, was isolated from peat swamp forest soil collected in Thailand. Its taxonomic position was determined by using a polyphasic taxonomic approach. The chemotaxonomic characteristics of this strain matched those of the genus Micromonospora, i.e. the presence of meso-diaminopimelic acid and $N$-glycolyl muramic acid in the peptidoglycan, whole-cell sugar pattern D, phospholipid type II, and cellular fatty acid type 3b. Phylogenetic analysis based on $16 \mathrm{~S}$ rRNA gene sequences revealed a close relationship between strain P0402 ${ }^{\top}$ and Micromonospora coxensis JCM 13248 ${ }^{\top}$ (99.0\% similarity), Micromonospora eburnea JCM $12345^{\top}$ (99.0\%), Micromonospora marina JCM 12870 ${ }^{\top}$ (98.9\%), Micromonospora halophytica JCM $3125^{\top}$ (98.7\%), Micromonospora chalcea JCM $3031^{\top}$ (98.7\%), Micromonospora purpureochromogenes JCM 3156 ${ }^{\top}(98.6 \%)$ and Micromonospora aurantiaca JCM $10878^{\top}(98.5 \%)$. It could be clearly distinguished from these type strains based on low levels of DNA-DNA relatedness and phenotypic differences. On the basis of the data presented, strain $\mathrm{P} 0402^{\top}$ is suggested to represent a novel species of the genus Micromonospora, for which the name Micromonospora humi sp. nov. is proposed. The type strain is $\mathrm{P}_{0402}{ }^{\top}\left(=\mathrm{JCM} 15292^{\top}=\mathrm{PCU} 315^{\top}=\right.$ TISTR $\left.1883^{\top}\right)$.
\end{abstract}

Micromonospora is a genus of the family Micromonosporaceae that was described by Ørskov (1923). Strains representing members of the genus Micromonospora have distinct morphological characteristics in that they produce single spores on the substrate mycelium and lack aerial mycelium. The rate at which novel species of the genus Micromonospora have been discovered has increased (Kawamoto, 1989; Kasai et al., 2000; Hirsch et al., 2004; Kroppenstedt et al., 2005; Trujillo et al., 2005, 2006, 2007; Thawai et al., 2004, 2005a, b, 2007; Ara \& Kudo, 2007; Jongrungruangchok et al., 2008a, b; Huang et al., 2008; Garcia et al., 2010; Tanasupawat et al., 2010; Kirby \& Meyers, 2010; Wang et al., 2011). At the time of writing, there are 44 species of the genus Micromonospora with

The GenBank/EMBL/DDBJ accession number for the 16S rRNA gene sequence of strain $\mathrm{P} 0402^{\top}$ is GU459068.

Three supplementary tables are available with the online version of this paper. validly published names (Euzéby, 2010), many of which were isolated from Thailand, including Micromonospora auratinigra, M. eburnea, M. siamensis, M. narathiwatensis, M. chaiyaphumensis, M. krabiensis and M. marina (Thawai et al., 2004, 2005a, b, 2007; Jongrungruangchok et al., 2008a, b; Tanasupawat et al., 2010). In this study, we describe a novel strain of the genus Micromonospora isolated during an investigation of the biodiversity of actinomycetes in peat swamp forest soil in Thailand.

Strain $\mathrm{P} 0402^{\mathrm{T}}$ was isolated at Phu Sang National Park, Phayao province, in the northern part of Thailand by using wet heat at $70{ }^{\circ} \mathrm{C}$ for $15 \mathrm{~min}$ and the standard dilution technique on starch casein nitrate agar (Tanasupawat et al., 2010) supplemented with nystatin $\left(50 \mathrm{mg} \mathrm{l}^{-1}\right)$ and nalidixic acid $\left(20 \mathrm{mg} \mathrm{l}^{-1}\right)$. Plates were incubated at $30{ }^{\circ} \mathrm{C}$ for 14 days and a single colony was then transferred to and purified on yeast extract-malt extract agar [International Streptomyces Project (ISP) medium no. 2] as described by 
Shirling \& Gottlieb (1966). The pure isolate was maintained on ISP 2 slants at $4-10{ }^{\circ} \mathrm{C}$. Strain $\mathrm{P}_{0402}{ }^{\mathrm{T}}$ grown on ISP 2 for 14 days was observed by light microscopy. Cell morphology was observed by scanning electron microscopy (Itoh et al., 1989). The Hucker-Conn method was used for Gram staining (Hucker \& Conn, 1923). Phenotypic properties were examined by using standard methods (Arai, 1975; Williams \& Cross, 1971; Gordon et al., 1974). For determination of cultural characteristics, the strain was grown at $30{ }^{\circ} \mathrm{C}$ for 14 days on various agar media (Shirling \& Gottlieb, 1966; Asano \& Kawamoto, 1986) after which colony colours were determined with reference to Jacobson et al. (1958). Temperature, $\mathrm{pH}$ and $\mathrm{NaCl}$ concentration ranges for the growth of strain $\mathrm{P} 0402^{\mathrm{T}}$ were tested on ISP 2 at $30{ }^{\circ} \mathrm{C}$ for 14 days. Carbon utilization medium (ISP 9) supplemented with $1 \%$ sole carbon source was used to determine the carbon utilization profile of the strain. Production of melanin and $\mathrm{H}_{2} \mathrm{~S}$ was examined on tyrosine agar (ISP 7) and peptone iron agar (ISP 6).

For chemotaxonomic investigations, freeze-dried cells were collected from 4-day-old cultures grown in ISP 2 broth on a rotary shaker at $30{ }^{\circ} \mathrm{C}$. The cell-wall peptidoglycan was prepared by the method of Kawamoto et al. (1981). The isomer of diaminopimelic acid was determined by the TLC method of Staneck \& Roberts (1974). The $\mathrm{N}$-acyl group of the muramic acid in the peptidoglycan was analysed spectrophotometrically by using the method of Uchida \& Aida (1984). Isoprenoid quinones were extracted by the method of Collins et al. (1977) and were then analysed by HPLC with the chromatograph equipped with a Cosmosil 5C18 column $(4.6 \times 150 \mathrm{~mm}$; Nacalai Tesque). Whole-cell sugars were analysed according to Mikami \& Ishida (1983). Methyl esters of cellular fatty acids were prepared from cells grown on ISP 2, Nonomura's yeast-starch agar (NYS, JCM medium no. 61; per litre: $15 \mathrm{~g}$ soluble starch, $4 \mathrm{~g}$ yeast extract, $0.5 \mathrm{~g} \mathrm{~K}_{2} \mathrm{HPO}_{4}, 0.5 \mathrm{~g} \mathrm{MgSO}_{4} \cdot 7 \mathrm{H}_{2} \mathrm{O}$ and $15 \mathrm{~g}$ agar, adjusted to $\mathrm{pH}$ 7.4) and sucrose Bennett's agar [SB, JCM medium no. 104; per litre: $1 \mathrm{~g}$ yeast extract, $1 \mathrm{~g}$ beef extract, $2 \mathrm{~g} \mathrm{~N}-\mathrm{Z}$ amine (type A), $10 \mathrm{~g}$ sucrose and $15 \mathrm{~g}$ agar, adjusted to $\mathrm{pH}$ 7.3] and were identified by GLC according to the Microbial Identification System (MIDI) (Sasser, 1990; Kämpfer \& Kroppenstedt, 1996) as described previously (Kudo et al., 1993). Phospholipids were extracted and analysed by the two-dimensional TLC method of Minnikin et al. (1984).

Chromosomal DNA was extracted from cells grown in ISP 2 broth supplemented with $0.1 \%$ glycine (Tamaoka, 1994; Yamada \& Komagata, 1970). The G+C content of the DNA was determined by HPLC (Tamaoka \& Komagata, 1984). Levels of DNA-DNA relatedness were determined according to Ezaki et al. (1989). The 16S rRNA gene was amplified by using primers $27 \mathrm{~F}$ and $1492 \mathrm{R}$ as described by Nakajima et al. (1999). The 16S rRNA gene sequence was multiply aligned with selected sequences obtained from the GenBank/EMBL/DDBJ databases by using the CLUSTAL_X program, version 1.83 (Thompson et al., 1997). The aligned sequences were manually edited before reconstruct- ing the phylogenetic tree by the neighbour-joining (Saitou \& Nei, 1987) and maximum-parsimony (Kluge \& Farris, 1969) methods in the MEGA 4 software (Tamura et al., 2007). Confidence levels for the branches of the phylogenetic tree were examined by bootstrap analysis (Felsenstein, 1985) based on 1000 resamplings. Gaps and ambiguous nucleotides were deleted manually before analysing sequence similarity values by CLUSTAL_X (Thompson et al., 1997).

Strain $\mathrm{P} 0402^{\mathrm{T}}$ had morphological, cultural and chemotaxonomic properties consistent with its classification in the genus Micromonospora. The strain formed welldeveloped and branched substrate hyphae. No aerial mycelium was produced. Spores at maturity were spherical to oval, smooth and non-motile (Fig. 1). The phenotypic characteristics of strain $\mathrm{P} 0402^{\mathrm{T}}$ are presented in the species description below and in Table 1 and Supplementary Table S1 (available in IJSEM Online). The strain contained mesodiaminopimelic acid in the cell wall. The acyl type of the cell wall in the peptidoglycan was determined to be the glycolyl type. Whole-cell sugars detected were glucose, xylose, mannose, ribose, galactose, arabinose and rhamnose [pattern D of Lechevalier \& Lechevalier (1970)]. The polar lipid profile comprised diphosphatidylglycerol, phosphatidylinositol, phosphatidylinositol mannosides and phosphatidylethanolamine [pattern type PII of Lechevalier et al. (1977)]. Predominant fatty acids of strain $\mathrm{P}_{0402}{ }^{\mathrm{T}}$ were iso- $\mathrm{C}_{15: 0}(12.72 \%)$, iso- $\mathrm{C}_{16: 0}(22.61 \%)$, anteiso- $\mathrm{C}_{17: 0}$ $(7.47 \%), \mathrm{C}_{17: 0}(13.56 \%), \mathrm{C}_{17: 1} \omega 8 c(12.51 \%)$ and anteiso- $\mathrm{C}_{15: 0}(10.61 \%)$ (Supplementary Table S2). This pattern corresponded to fatty acid type $3 \mathrm{~b}$ of Kroppenstedt (1985). The predominant menaquinones were MK-10 $\left(\mathrm{H}_{4}\right)$ $(64.5 \%)$ and MK-10 $\left(\mathrm{H}_{6}\right)(35.6 \%)$. The DNA G+C content of strain $\mathrm{P} 0402^{\mathrm{T}}$ was $73.0 \mathrm{~mol} \%$.

Analysis of the almost-complete $16 \mathrm{~S}$ rRNA gene sequence (1478 nt) of strain $\mathrm{P} 0402^{\mathrm{T}}$ indicated that it was placed in a monophyletic clade with Micromonospora coxensis JCM $13248^{\mathrm{T}}$ (99.0 \% similarity), M. eburnea JCM $12345^{\mathrm{T}}$ (99.0\%), M. marina JCM $12870^{\mathrm{T}}(98.9 \%)$, Micromonospora halophy-

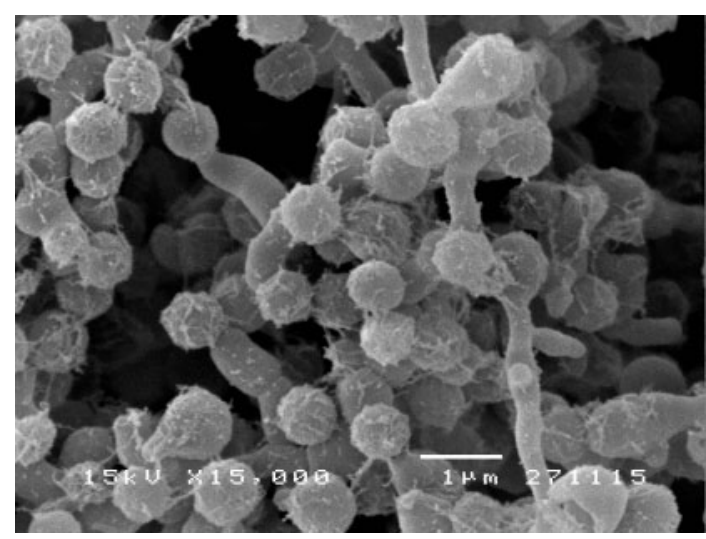

Fig. 1. Scanning electron micrograph of cells of strain $P 0402^{\top}$ grown on ISP 2 agar medium at $30{ }^{\circ} \mathrm{C}$ for 14 days. Bar, $1 \mu \mathrm{m}$. 


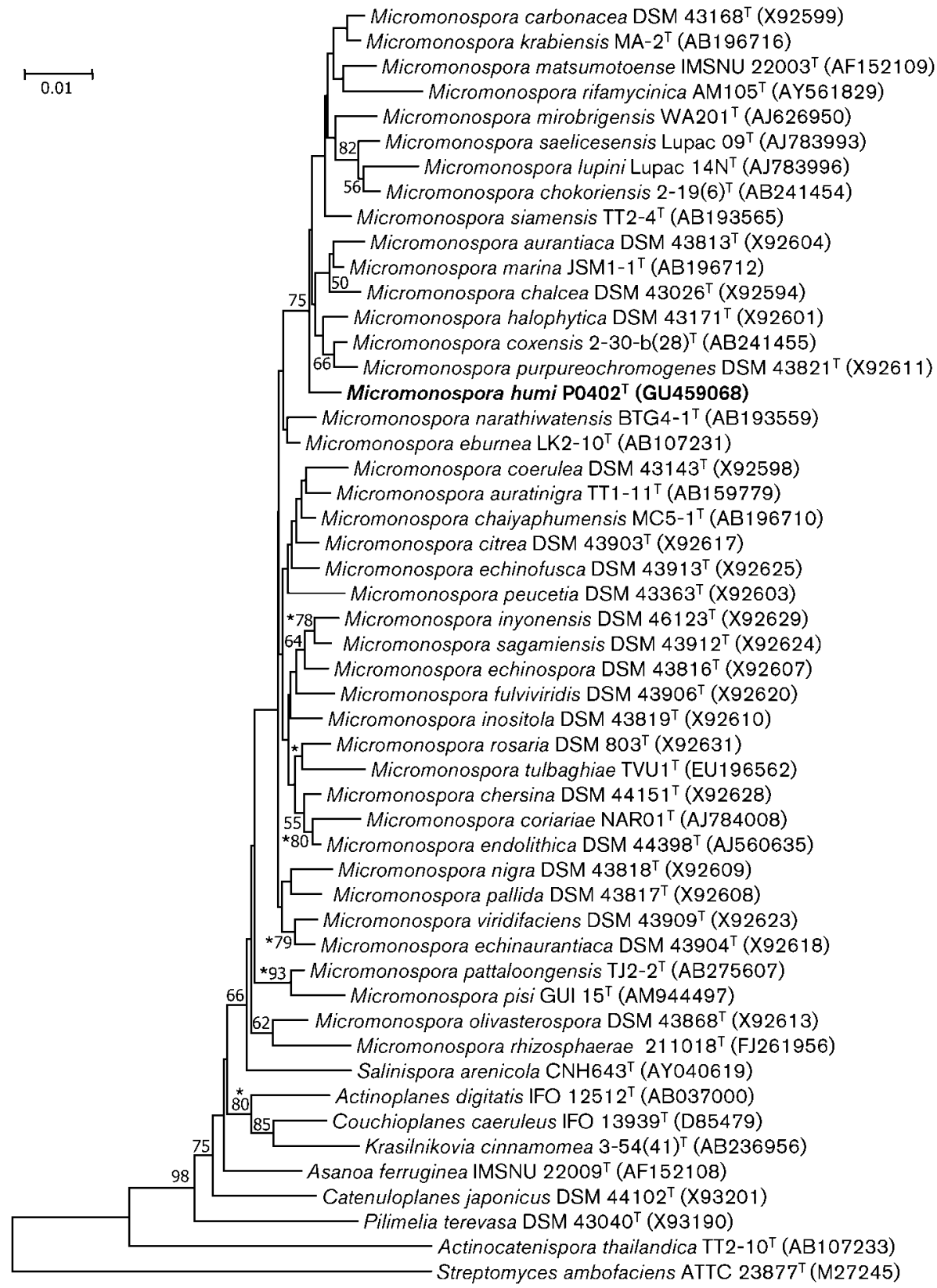

Fig. 2. Neighbour-joining tree based on almost-complete $16 \mathrm{~S}$ rRNA gene sequences showing relationships among strain $\mathrm{PO402}^{\top}$, the type strains of recognized species of the genus Micromonospora and representatives of the family Micromonosporaceae. Streptomyces ambofaciens ATCC $23877^{\top}$ was used as an outgroup. Asterisks indicate branches of the tree that were also found by using the maximum-parsimony method. The numbers on the branches indicate the percentage bootstrap values based on 1000 replicates; only values $\geqslant 50 \%$ are indicated. Bar, 0.01 substitutions per nucleotide position.

tica JCM $3125^{\mathrm{T}}(98.7 \%)$, Micromonospora chalcea JCM $3031^{\mathrm{T}}$ (98.7\%), Micromonospora purpureochromogenes JCM $3156^{\mathrm{T}}$ $(98.6 \%)$ and Micromonospora aurantiaca JCM $10878^{\mathrm{T}}$ $(98.5 \%)$, based on the results from both the neighbourjoining and the maximum-parsimony methods (Fig. 2). Comparison with the descriptions of these previously characterized species of the genus Micromonospora showed that strain $\mathrm{P} 0402^{\mathrm{T}}$ could be distinguished from them based on a combination of biochemical and physiological properties, in particular decomposition of L-tyrosine, utilization of $\mathrm{D}$ fructose, glycerol, melibiose, raffinose and D-ribose, growth at $\mathrm{pH}$, and maximum $\mathrm{NaCl}$ tolerance (5\%) (Table 1).

Levels of DNA-DNA relatedness between strain $\mathrm{P} 0402^{\mathrm{T}}$ and the type strains of the above species were $\leqslant 15.19 \%$ (Supplementary Table S3). These values were obtained 
Table 1. Differential characteristics between strain $P 0402^{\top}$ and the type strains of related species of the genus Micromonospora

Strains: 1 , P0402 ${ }^{\mathrm{T}} ; 2$, M. coxensis JCM $13248^{\mathrm{T}} ; 3$, M. eburnea JCM $12345^{\mathrm{T}}$ (data from Thawai et al., 2005a); 4, M. marina JCM $12870^{\mathrm{T}}$ (Tanasupawat

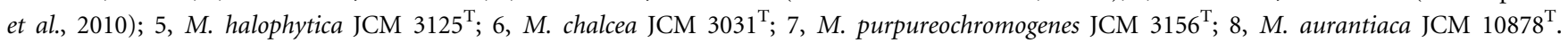
$\mathrm{W}$, Weakly positive.

\begin{tabular}{|c|c|c|c|c|c|c|c|c|}
\hline Characteristic & 1 & 2 & 3 & 4 & 5 & 6 & 7 & 8 \\
\hline Decomposition of tyrosine & - & - & - & + & - & - & - & + \\
\hline Growth at $\mathrm{pH} 5$ & + & $\mathrm{w}$ & + & + & - & - & - & + \\
\hline \multicolumn{9}{|l|}{ Utilization of: } \\
\hline L-Arabinose & + & + & - & + & + & $\mathrm{w}$ & - & $\mathrm{W}$ \\
\hline D-Fructose & - & + & - & + & + & $\mathrm{w}$ & + & + \\
\hline Lactose & + & + & + & - & + & + & $\mathrm{w}$ & - \\
\hline Melibiose & - & + & + & + & + & + & + & + \\
\hline Raffinose & - & + & + & + & + & + & + & - \\
\hline D-Ribose & - & - & - & + & - & - & - & - \\
\hline
\end{tabular}

from the means of three determinations and are below the threshold value of $70 \%$ for distinguishing genomic species (Wayne et al., 1987). It is evident from the genotypic and phenotypic data presented that strain $\mathrm{P} 0402^{\mathrm{T}}$ represents a novel species of the genus Micromonospora, for which the name Micromonospora humi sp. nov. is proposed.

\section{Description of Micromonospora humi sp. nov.}

Micromonospora humi sp. nov. (hu'mi. L. gen. n. humi of earth, soil, the source from which the type strain was isolated).

Aerobic, Gram-stain-positive, mesophilic actinomycete that forms a well-developed and extensively branched substrate mycelium. No aerial mycelium is produced. The colour of the vegetative mycelium on ISP 2 is sepia brown, turning to brownish black upon sporulation. Spores are spherical to oval, smooth and non-motile. Positive for starch hydrolysis, gelatin liquefaction and milk peptonization. Negative for nitrate reduction and L-tyrosine decomposition. Utilizes L-arabinose, D-galactose, D-glucose and lactose as sole carbon sources for energy, but not D-fructose, glycerol, raffinose, D-mannitol, L-rhamnose, inositol, melibiose, cellobiose, D-ribose or salicin. Grows at 20-30 ${ }^{\circ} \mathrm{C}$, at $\mathrm{pH} 5-8$ and in the presence of up to $5 \%$ $\mathrm{NaCl}$. Grows optimally at $30{ }^{\circ} \mathrm{C}$, at $\mathrm{pH} 7.3-8$ and in the presence of $<4 \% \mathrm{NaCl}$. The cell-wall peptidoglycan contains glutamic acid, alanine and meso-diaminopimelic acid. The acyl type of the cell wall is glycolyl. The predominant menaquinones are $\mathrm{MK}-10\left(\mathrm{H}_{4}\right)$ and $\mathrm{MK}$ $10\left(\mathrm{H}_{6}\right)$. Major cellular fatty acids are iso- $\mathrm{C}_{15: 0}$, iso- $\mathrm{C}_{16: 0}$, $\mathrm{C}_{17: 0}, \mathrm{C}_{17: 1} \omega 8 c$ and anteiso- $\mathrm{C}_{15: 0 .}$. The DNA $\mathrm{G}+\mathrm{C}$ content of the type strain is $73.0 \mathrm{~mol} \%$.

The type strain, $\mathrm{P} 0402^{\mathrm{T}}\left(=\mathrm{JCM} 15292^{\mathrm{T}}=\mathrm{PCU} 315^{\mathrm{T}}=\right.$ TISTR $1883^{\mathrm{T}}$ ), was isolated from peat swamp forest soil in Thailand.

\section{Acknowledgements}

This study was supported by the Thailand Research Fund for a 2006 Royal Golden Jubilee PhD Program as a scholarship to A.S. and in part by the Faculty of Pharmaceutical Sciences Research Fund (2006), Chulalongkorn University, Bangkok, Thailand.

\section{References}

Ara, I. \& Kudo, T. (2007). Two new species of the genus Micromonospora: Micromonospora chokoriensis sp. nov. and Micromonospora coxensis sp. nov., isolated from sandy soil. J Gen Appl Microbiol 53, 29-37.

Arai, T. (1975). Culture Media for Actinomycetes. Tokyo: The Society for Actinomycetes Japan.

Asano, K. \& Kawamoto, I. (1986). Catellatospora, a new genus of the Actinomycetales. Int J Syst Bacteriol 36, 512-517.

Collins, M. D., Pirouz, T., Goodfellow, M. \& Minnikin, D. E. (1977). Distribution of menaquinones in actinomycetes and corynebacteria. J Gen Microbiol 100, 221-230.

Euzéby, J. P. (2010). List of bacterial names with standing in nomenclature. http://www.bacterio.cict.fr/.

Ezaki, T., Hashimoto, Y. \& Yabuuchi, E. (1989). Fluorometric deoxyribonucleic acid-deoxyribonucleic acid hybridization in microdilution wells as an alternative to membrane filter hybridization in which radioisotopes are used to determine genetic relatedness among bacterial strains. Int J Syst Bacteriol 39, 224-229.

Felsenstein, J. (1985). Confidence limits on phylogenies: an approach using the bootstrap. Evolution 39, 783-791.

Garcia, L. C., Martínez-Molina, E. \& Trujillo, M. E. (2010). Micromonospora pisi sp. nov., isolated from root nodules of Pisum sativum. Int J Syst Evol Microbiol 60, 331-337.

Gordon, R. E., Barnett, D. A., Handerhan, J. E. \& Pang, C. H.-N. (1974). Nocardia coeliaca, Nocardia autotrophica, and the nocardin strain. Int J Syst Bacteriol 24, 54-63.

Hirsch, P., Mevs, U., Kroppenstedt, R. M., Schumann, P. \& Stackebrandt, E. (2004). Cryptoendolithic actinomycetes from antarctic sandstone rock samples: Micromonospora endolithica sp. nov. and two isolates related to Micromonospora coerulea Jensen 1932. Syst Appl Microbiol 27, 166-174. 
Huang, H., Lv, J., Hu, Y., Fang, Z., Zhang, K. \& Bao, S. (2008). Micromonospora rifamycinica sp. nov., a novel actinomycete from mangrove sediment. Int J Syst Evol Microbiol 58, 17-20.

Hucker, G. J. \& Conn, H. J. (1923). Method of gram staining. Tech Bull N Y St Agric Exp Stn 93, 3-37.

Itoh, T., Kudo, T., Parenti, F. \& Seino, A. (1989). Amended description of the genus Kineosporia, based on chemotaxonomic and morphological studies. Int J Syst Bacteriol 39, 168-173.

Jacobson, E., Grauville, W. C. \& Fogs, C. E. (1958). Colour Harmony Manual, 4th edn. Chicago: Container Corporation of America.

Jongrungruangchok, S., Tanasupawat, S. \& Kudo, T. (2008a). Micromonospora chaiyaphumensis sp. nov., isolated from Thai soils. Int J Syst Evol Microbiol 58, 924-928.

Jongrungruangchok, S., Tanasupawat, S. \& Kudo, T. (2008b). Micromonospora krabiensis sp. nov., isolated from marine soil in Thailand. J Gen Appl Microbiol 54, 127-133.

Kämpfer, P. \& Kroppenstedt, R. M. (1996). Numerical analysis of fatty acid patterns of coryneform bacteria and related taxa. Can $J$ Microbiol 42, 989-1005.

Kasai, H., Tamura, T. \& Harayama, S. (2000). Intrageneric relationships among Micromonospora species deduced from gyr $B$-based phylogeny and DNA relatedness. Int J Syst Evol Microbiol 50, 127134.

Kawamoto, I. (1989). Genus Micromonospora Ørskov 1923, $147^{\mathrm{AL}}$. In Bergey's Manual of Systematic Bacteriology, vol. 4, pp. 2442-2450. Edited by S. T. Williams, M. E. Sharpe \& J. G. Holt. Baltimore: Williams \& Wilkins.

Kawamoto, I., Oka, T. \& Nara, T. (1981). Cell wall composition of Micromonospora olivoasterospora, Micromonospora sagamiensis, and related organisms. J Bacteriol 146, 527-534.

Kirby, B. M. \& Meyers, P. R. (2010). Micromonospora tulbaghiae sp. nov., isolated from the leaves of wild garlic, Tulbaghia violacea. Int $J$ Syst Evol Microbiol 60, 1328-1333.

Kluge, A. G. \& Farris, F. S. (1969). Quantitative phyletics and the evolution of anurans. Syst Zool 18, 1-32.

Kroppenstedt, R. M. (1985). Fatty acid and menaquinone analysis of actinomycetes and related organisms. In Chemical Methods in Bacterial Systematics, pp. 173-199. Edited by M. Goodfellow \& D. E. Minnikin. London: Academic Press.

Kroppenstedt, R. M., Mayilraj, S., Wink, J. M., Kallow, W., Schumann, P., Secondini, C. \& Stackebrandt, E. (2005). Eight new species of the genus Micromonospora, Micromonospora citrea sp. nov., Micromonospora echinaurantiaca sp. nov., Micromonospora echinofusca sp. nov. Micromonospora fulviviridis sp. nov., Micromonospora inyonensis sp. nov., Micromonospora peucetia sp. nov., Micromonospora sagamiensis sp. nov., and Micromonospora viridifaciens sp. nov. Syst Appl Microbiol 28, 328-339.

Kudo, T., Itoh, T., Miyadoh, S., Shomura, T. \& Seino, A. (1993). Herbidospora gen. nov., a new genus of the family Streptosporangiaceae Goodfellow et al. 1990. Int J Syst Bacteriol 43, 319-328.

Lechevalier, M. P. \& Lechevalier, H. (1970). Chemical composition as a criterion in the classification of aerobic actinomycetes. Int J Syst Bacteriol 20, 435-443.

Lechevalier, M. P., De Bievre, C. \& Lechevalier, H. (1977). Chemotaxonomy of aerobic actinomycetes: phospholipid composition. Biochem Syst Ecol 5, 249-260.

Mikami, H. \& Ishida, Y. (1983). Post-column fluorometric detection of reducing sugars in high performance liquid chromatography using arginine. Bunseki Kagaku 32, E207-E210.

Minnikin, D. E., O'Donnell, A. G., Goodfellow, M., Alderson, G., Athalye, M. \& Parlett, J. H. (1984). An integrated procedure for the extraction of bacterial isoprenoid quinones and polar lipids. J Microbiol Methods 2, 233-241.

Nakajima, Y., Kitpreechavanich, V., Suzuki, K. \& Kudo, T. (1999). Microbispora corallina sp. nov., a new species of the genus Microbispora isolated from Thai soil. Int J Syst Bacteriol 49, 17611767.

Ørskov, J. (1923). Investigations into the Morphology of the Ray Fungi. Copenhagen: Levin and Munksgaard.

Saitou, N. \& Nei, M. (1987). The neighbor-joining method: a new method for reconstructing phylogenetic trees. Mol Biol Evol 4, 406425.

Sasser, M. (1990). Identification of bacteria by gas chromatography of cellular fatty acids, MIDI Technical Note 101. Newark, DE: MIDI.

Shirling, E. B. \& Gottlieb, D. (1966). Methods for characterization of Streptomyces species. Int J Syst Bacteriol 16, 313-340.

Staneck, J. L. \& Roberts, G. D. (1974). Simplified approach to identification of aerobic actinomycetes by thin-layer chromatography. Appl Microbiol 28, 226-231.

Tamaoka, J. (1994). Determination of DNA base composition. In Chemical Methods in Prokaryotic Systematics, pp. 463-470. Edited by M. Goodfellow \& A. G. O'Donnell. Chichester: Wiley.

Tamaoka, J. \& Komagata, K. (1984). Determination of DNA base composition by reversed-phase high-performance liquid chromatography. FEMS Microbiol Lett 25, 125-128.

Tamura, K., Dudley, J., Nei, M. \& Kumar, S. (2007). MEGA 4: molecular evolutionary genetics analysis (MEGA) software version 4.0. Mol Biol Evol 24, 1596-1599.

Tanasupawat, S., Jongrungruangchok, S. \& Kudo, T. (2010). Micromonospora marina sp. nov., isolated from sea sand. Int J Syst Evol Microbiol 60, 648-652.

Thawai, C., Tanasupawat, S., Itoh, T., Suwanborirux, K. \& Kudo, T. (2004). Micromonospora aurantionigra sp. nov., isolated from a peat swamp forest in Thailand. Actinomycetologica 18, 8-14.

Thawai, C., Tanasupawat, S., Itoh, T., Suwanborirux, K., Suzuki, K. \& Kudo, T. (2005a). Micromonospora eburnea sp. nov., isolated from a Thai peat swamp forest. Int J Syst Evol Microbiol 55, 417-422.

Thawai, C., Tanasupawat, S., Itoh, T., Suwanborirux, K. \& Kudo, T. (2005b). Micromonospora siamensis sp. nov., isolated from Thai peat swamp forest. J Gen Appl Microbiol 51, 229-234.

Thawai, C., Tanasupawat, S., Suwanborirux, K., Itoh, T. \& Kudo, T. (2007). Micromonospora narathiwatensis sp. nov., from Thai peat swamp forest soils. J Gen Appl Microbiol 53, 287-293.

Thompson, J. D., Gibson, T. J., Plewniak, F., Jeanmougin, F. \& Higgins, D. G. (1997). The CLUSTAL_X windows interface: flexible strategies for multiple sequence alignment aided by quality analysis tools. Nucleic Acids Res 25, 4876-4882.

Trujillo, M. E., Fernández-Molinero, C., Velázquez, E., Kroppenstedt, R. M., Schumann, P., Mateos, P. F. \& Martínez-Molina, E. (2005). Micromonospora mirobrigensis sp. nov. Int J Syst Evol Microbiol 55, 877-880.

Trujillo, M. E., Kroppenstedt, R. M., Schumann, P., Carro, L. \& Martínez-Molina, E. (2006). Micromonospora coriariae sp. nov., isolated from root nodules of Coriaria myrtifolia. Int J Syst Evol Microbiol 56, 2381-2385.

Trujillo, M. E., Kroppenstedt, R. M., Fernández-Molinero, C., Schumann, P. \& Martínez-Molina, E. (2007). Micromonospora lupini sp. nov. and Micromonospora saelicesensis sp. nov., isolated from root nodules of Lupinus angustifolius. Int J Syst Evol Microbiol 57, 27992804 . 
Uchida, K. \& Aida, K. (1984). An improved method for the glycolate test for simple identification of the acyl type of bacterial cell walls. J Gen Appl Microbiol 30, 131-134.

Wang, C., Xu, X.-X., Qu, Z., Wang, H.-L., Lin, H.-P., Xie, Q.-Y., Ruan, J.-S. \& Hong, K. (2011). Micromonospora rhizosphaerae sp. nov., isolated from mangrove rhizosphere soil. Int J Syst Evol Microbiol 61, 320-324.

Wayne, L. G., Brenner, D. J., Colwell, R. R., Grimont, P. A. D., Kandler, O., Krichevsky, M. I., Moore, L. H., Moore, W. E. C., Murray, R. G. E. \& other authors (1987). International Committee on Systematic Bacteriology. Report of the ad hoc committee on the reconciliation of approaches to bacterial systematics. Int J Syst Bacteriol 37, 463-464.

Williams, S. T. \& Cross, T. (1971). Actinomycetes. Methods Microbiol 4, 295-334.

Yamada, K. \& Komagata, K. (1970). Taxonomic studies on coryneform bacteria. III. DNA base composition of coryneform bacteria. J Gen Appl Microbiol 16, 215-224. 